\title{
EVALUATION OF BUCHAREST SOIL LIQUEFACTION POTENTIAL
}

\author{
ARION CRISTIAN - Lecturer, PhD, Technical University of Civil Engineering, e-mail: arion@utcb.ro \\ CALARASU ELENA -Researcher, PhD, URBAN-INCERC Bucharest \\ NEAGU CRISTIAN - Researcher, PhD Student, Technical University of Civil Engineering, e-mail: cristi.neagu@utcb.ro
}

\begin{abstract}
The paper contains the experimental research performed in Bucharest like the borehole data (Standard Penetration Test) and the data obtained from seismic investigations (down-hole prospecting and surface-wave methods). The evaluation of the soils liquefaction resistance based on the results of the SPT, down-hole prospecting and surface-wave method tests and the use of the earthquake records will be presented.
\end{abstract}

Keywords: Bucharest, liquefaction, SPT, seismic prospecting

\section{Introduction}

The Bucharest metropolitan area is located in the Romanian Plain, along the Colentina and Dambovita rivers, in the central part of the Moesian Sub-plate (age: Precambrian and Paleozoic). Over Cretaceous and Miocene deposits (having the top at about $1000 \mathrm{~m}$ depth) a Pliocene shallow water deposit $(\sim 700 \mathrm{~m}$ thick) was settled. The surface geology consists mainly of Quaternary alluvial deposits with distinct peculiarities and large intervals of thickness characterize the city of Bucharest. Later loess covered these deposits and rivers shaped the present landscape [1].

The main source of earthquakes for Bucharest is the Vrancea seismic zone. When strong ground motions were recorded, they provided instrumental proofs of site effects. Site effects were firstly observed on the basis of damage pattern within the city.

The borehole data and the experimental research performed in the last years revealed a new series of elements regarding the stratification and soil characteristics and of the long predominant period of soil vibration that characterize Bucharest [2].

The strong November 10, 1940 Vrancea earthquake (moment magnitude MW=7.7) represents the starting point of earthquake engineering in Romania. The earthquake triggered liquefaction at many sites including Bucharest, the water blowing out up to $1 \mathrm{~m}$ height. During March 4, 1977 Vrancea strong earthquake ( $\mathrm{MW}=7.5)$, the most destructive earthquake ever experienced in Romania, not only man-made structures and buildings suffered, but also geological and hydrological elements were disturbed at many sites in Romania. Permanent ground settlement in Bucharest measured after 1977 event was uniform of 0.2-2.5cm for 11-12 storeys buildings [3].

\section{In situ prospecting methods used at various sites in Bucharest area}

\subsection{Standard Penetration Test (Spt)}

The method represents one of the most used geotechnical method for in situ soil investigation. The SPT is a combined method of sampling and in situ testing applied in a borehole. The Standard Penetration Test is used to identify the soil stratification, the layer thickness in order to estimate the geological and hydrogeological conditions, to determine the strength, deformation soil characteristics and other engineering properties of soil layers being generally recommended 
for geotechnical investigations of soil surface $(<40 \mathrm{~m})$. The method is easy and possible to apply to different soil types. It is most often used in granular materials but also in other materials when simple in-place bearing strengths are required. The results of the SPT measurements are quantified in the number of blows required to affect that segment of penetration, NSPT. The relative firmness or consistency of cohesive soils or density of cohesionless soils can be estimated from the blow count data. In addition, there are many geotechnical correlations, which relate SPT blow count, or N-value, and geotechnical behavior. The $\mathrm{N}$-value becomes a guideline of hardness and softness of soil (the foundation material). Many local correlations as well as widely published correlations, which relate SPT blow count and the engineering behavior of earthworks and foundations are available. The resistance to penetration is obtained by counting the number of blows required to drive a steel tube of specified dimensions into the subsoil to a specified distance using a hammer of a specified weight (mass). The SPT equipment, SPT splitbarrel sampler and the drill rods used for soil penetration test are shown in Figure 1, and the soil sampling is presented in Figure 2.

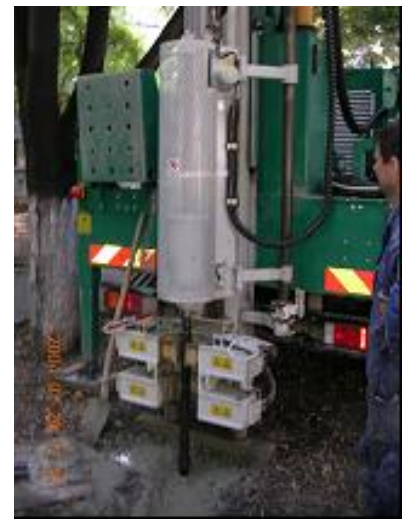

Fig. 1 - Standard Penetration equipment

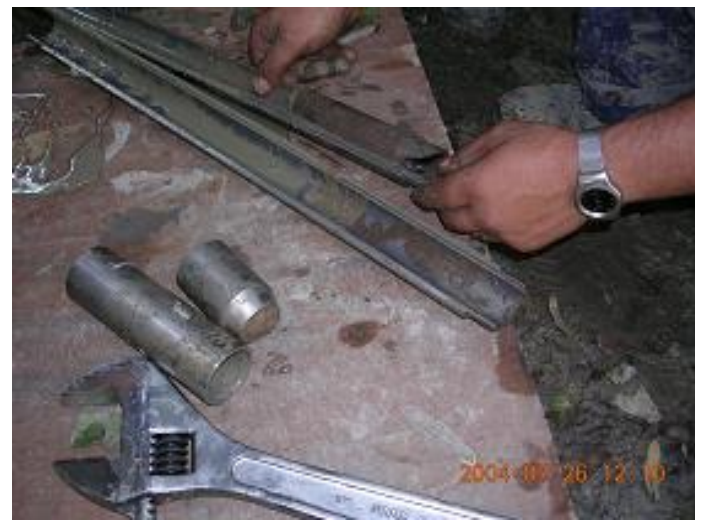

Fig. 2 - Soil sampling using SPT

In many countries, Standard Penetration Test remains the subsurface investigation technique of choice for geotechnical engineers. The testing procedure varies in different parts of the world. Therefore, standardization of SPT was essential in order to facilitate the comparison of results from different investigations. SPT standards used in different countries are as follows: Japan JIS A 1219-2001, United States of America (USA) - ASTM, D 1586-2000, United Kingdom (UK) -BS 5930:1981, European Standard - ISO 22476-3:2005 „Standard Penetration Test”, EUROCODE 7 (ENV), Part 3 „Design assisted by field testing”, 1997, revised in 1999, Romania - SR EN ISO 22476-3:2006 "Geotechnical investigation and testing - Field testing - Part 3: Standard Penetration Test.

\subsection{Geophysical measurements}

\subsubsection{Downhole method}

The geophysical measurements of surface geology in Romania were developed in last years, especially by the promoting of down-hole types by using PS Logging method. The method use the measurement of seismic waves arrival times generated by an impulse source, located at ground surface and seismic waves travel to a sensor placed at some specific borehole depth. The analysis of travel-time data coordinated with the site stratigraphy revealed the seismic velocity profiles and other related parameters as Young's modulus $\left(E_{\mathrm{din}}\right)$, shear modulus $\left(\mathrm{G}_{\mathrm{din}}\right)$ and Poisson's ratio $\left(v_{\mathrm{din}}\right)$.

\subsubsection{Surface wave method (SASW)}

Surface-wave (Rayleigh wave) is elastic waves propagating along the ground surface and its energy concentrates near the ground surface. The surface-wave velocity of propagation strongly 
depends on S-wave velocity. The surface wave method is the seismic exploration method in which the dispersion character of the surface-waves is analyzed. The surface-wave method can be carried out from ground surface non-destructively [4]. Figure 3 shows the schematic view of a surface-wave method. A $10 \mathrm{~kg}$ sledgehammer or $50 \mathrm{~kg}$ weight drops are used as a source. The sources are placed with 1 to $4 \mathrm{~m}$ intervals. 12 to 48 geophones $(4.5 \mathrm{~Hz})$ are deployed with 0.5 to $2 \mathrm{~m}$ intervals. The result of measurements of the shear-wave velocity at UTCB is presented in Figure 4.
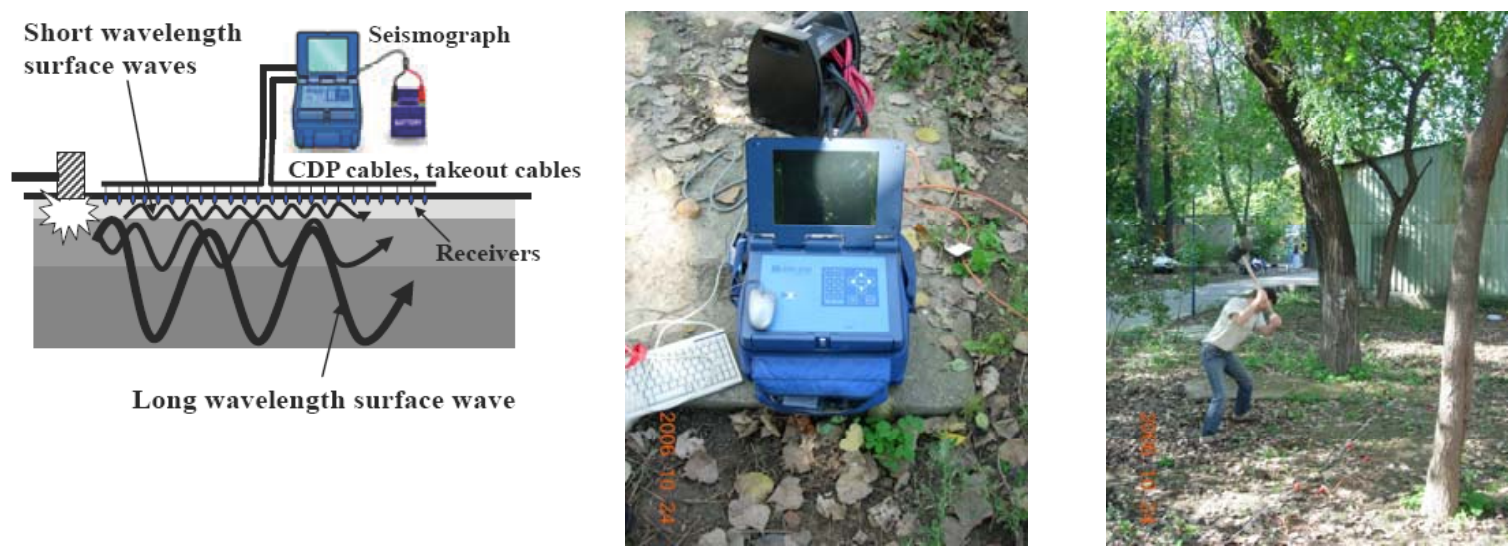

Fig. 3 - Schematic diagram of a surface-wave method
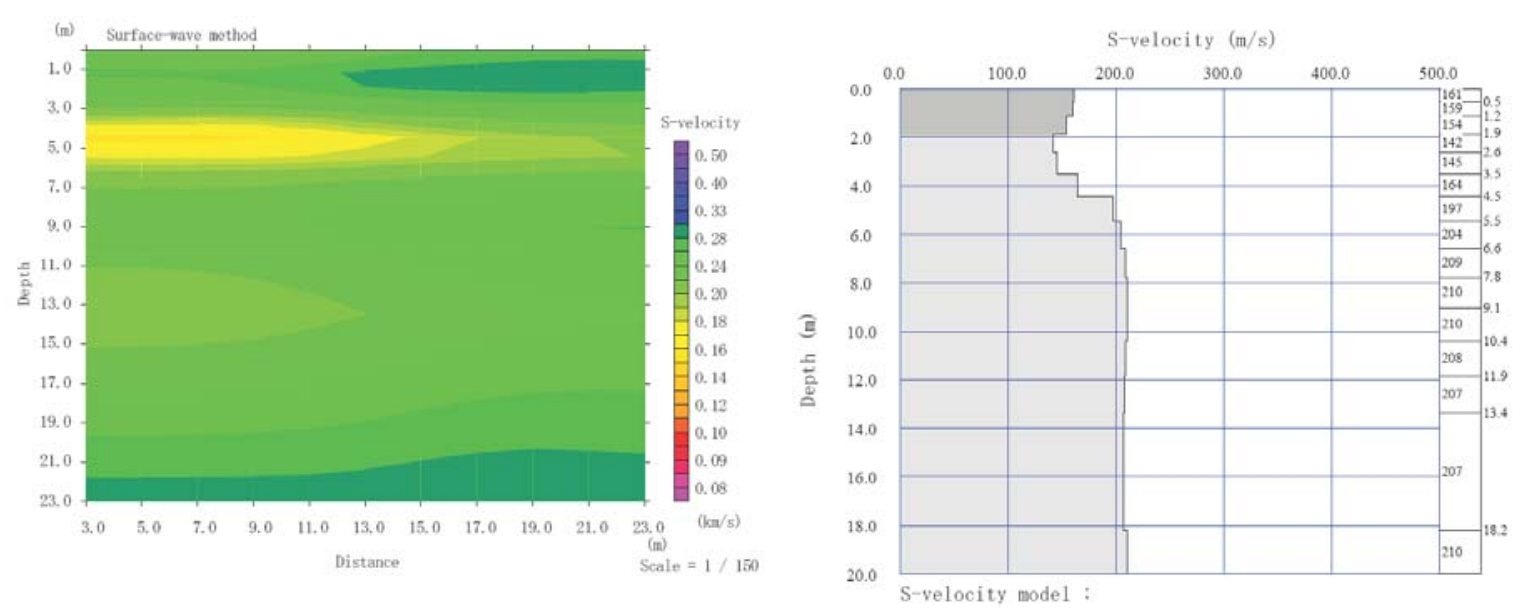

Fig. 4 - Shear-wave velocity profiles for the UTCB site

\section{Evaluation of soil liquefaction resistance using field data}

It is known that one of the seismic motions effects on soil and implicitly on building safety is represented by the appearance of liquefaction phenomenon in saturated cohesionless deposits.

The most common cause of ground failure during earthquake is the liquefaction phenomenon that has produced severe damage all over the world. The liquefaction of sandy soils and sands with non-plastic fines as a result of earthquake ground shaking poses a major threat to the safety of civil engineering structures. The current state-of-practice is described by [5]. It is widely accepted that only the recent sediments or fills of saturated, cohesionless soils at shallow depths $\left(<20\right.$ meters) will liquefy in a large magnitude earthquake $\left(\mathrm{M}_{\mathrm{w}}>7\right)$.

In Bucharest, during the strong Vrancea earthquakes the liquefaction was reported at few sites in Dambovita river meadow and it did not damaged buildings or foundations. The important researches regarding the appearance of cohesionless liquefactions after the 1977 Vrancea earthquake in Bucharest were those developed by [6]. In the present paper, for the evaluation of 
liquefaction potential, three sites within $500 \mathrm{~m}$, located on the left bank of the river Dambovita will be presented, using the input data obtained from SPT, downhole and SASW measurements. In case of present analysis procedure, the assessment of soil liquefaction potential is obtained for an earthquake scenario with the following parameters: $\mathrm{M}_{\mathrm{w}}=7.5$ and $\mathrm{a}_{\max }=0,30 \mathrm{~g}$.

\subsection{Evaluation of soil liquefaction resistance using SPT results}

The liquefaction resistance of soil deposits and prediction of the liquefied thickness is based on Standard Penetration Test blow counts in a single boring log. Starting in the 1970's, H.B. Seed and his colleagues worked to develop a reliable method for assessing the liquefaction potential based on SPT data. Their framework for SPT-based assessments of liquefaction potential was developed in a series of papers that includes [7], [8], [9], significant contributions were also suggested in the work of Tokimatsu [10] and [11].

The empirical method in evaluating the soil liquefaction resistance from Standard Penetration Test blow counts is based on corrected values of $\left(\mathrm{N}_{1}\right)_{60}$ and cyclic resistance ratio, CSR.

The first step in evaluating the soil liquefaction resistance is to correct the measured SPT blow counts $\mathrm{N}_{\mathrm{SPT}}$. The measured SPT blow counts is first normalized for the overburden stress at the depth of the test and corrected to a standardized value of $\left(\mathrm{N}_{1}\right)_{60}$ :

$$
\left(N_{1}\right)_{60}=N_{S P T} \cdot C_{N} \cdot C_{E} \cdot C_{B} \cdot C_{S} \cdot C_{R}
$$

where:

$N_{S P T}$ represents the blow counts necessary for $30 \mathrm{~cm}$ soil penetration;

$C_{N}, C_{E}, C_{B}, C_{S}, C_{R}$ are the correction factors.

The next step in the liquefaction analysis procedure is to find the cyclic resistance ratio (CRR) for the soil based on the computed clean-sand equivalent $\left(\left(\mathrm{N}_{1}\right)_{60 \mathrm{cs}}\right)$. This is done using the empirical base curve drawn from the liquefaction catalogue for a magnitude 7.5 earthquake, according to [12] recommendation. The mathematical expression implemented for determining the cyclic resistance ratio for soil is:

$$
100 \cdot C R R_{M=7.5}=\frac{95}{34-\left(N_{1}\right)_{60 c s}}+\frac{\left(N_{1}\right)_{60 c s}}{1.3}-\frac{1}{2}
$$

where:

$C R R$ is the cyclic resistance ratio for a $\mathrm{M}_{\mathrm{w}}=7.5$ earthquake;

$\left(N_{1}\right)_{60 c s}$ represents the clean-sand equivalent $S P T$ value.

The value of $\mathrm{CRR}_{\mathrm{M}=7.5}$ must be adjusted for the magnitude of the earthquake under consideration. This is adjusted with a magnitude scaling factor, MSF:

$$
C R R=C R R_{M=7.5} \cdot M S F \cdot K_{\sigma}
$$

where:

CRR is the cyclic resistance ratio of the soil for an earthquake magnitude corresponding to MSF, which can be considered by assuming that the main effect of different magnitude earthquakes on liquefaction resistance is the number of significant stress cycles generated. The magnitude scaling factors is considered $\mathrm{MSF}=1$ for an earthquake with moment magnitude $\mathrm{M}_{\mathrm{w}}=7,5$ 
according to [9]. The $K_{\sigma}$ factor, a correction for overload, is calculated from the following formula:

$$
K_{\sigma}=1-C_{\sigma} \ln \left(\frac{\sigma_{v}^{\prime}}{P_{a}}\right) \leq 1.1
$$

Once the liquefaction resistance is known at a certain depth, the average cyclic shear stress generated by an earthquake must be estimated. The representative horizontal shear stress is computed with a simplified equation suggested by [7] and expressed in terms of the cyclic stress ratio $(\mathrm{CSR})$ :

$$
C S R=0.65 \cdot \frac{a_{\max }}{g} \cdot \frac{\sigma_{v o}}{\sigma_{v o}^{\prime}} \cdot r_{d}
$$

where:

$g=9.81 \mathrm{~m} / \mathrm{s}^{2}$ is the acceleration due to gravity, $\sigma_{v o}$ is the total vertical overburden stress, $\sigma_{v o}^{\prime}$ is the effective vertical overburden stress at the depth of interest, $a_{\max }$ is the maximum horizontal acceleration that would occur at the ground surface in the absence of excess pore pressures or liquefaction generated by the earthquake. The last parameter is the stress reduction factor, $r_{d}$, which accounts for soil flexibility as a function of depth, as simple linear equations [7].

The last step in the liquefaction analysis is to compute the factor of safety at each SPT location and the liquefied thickness. If the computed cyclic resistance ratio $(C R R)$ of the soil is less than or equal to cyclic stress ratio $(C S R)$ generated by an earthquake, liquefaction is assumed to occur at that location. The factor of safety against liquefaction, $F S_{\text {liq, }}$, is defined [13], [14] and [15]:

$$
F S_{\text {liq }}=\frac{C R R}{C S R}
$$

$F S_{\text {liq }} \leq 1.0$ indicates that the soil at the depth of the measured SPT is predicted to liquefy

$F S_{\text {liq }}>1.0$ indicates no liquefaction

One of the investigated sites (RD1) is located near Dambovita meadow, with a lithological profile represented by thick sandy soils and interposed clay and sandy clay intercalations and ground water table at 5,00 meters depth. The SPT N-values and the computed parameters, including the necessary corrections used in the literature, are summary presented in Table 1.

\begin{tabular}{|c|c|c|c|c|c|c|c|c|c|}
\hline \multirow[t]{2}{*}{ Point } & \multirow{2}{*}{$\begin{array}{l}\text { Depth } \\
\text { (m) }\end{array}$} & \multicolumn{2}{|c|}{$\begin{array}{c}\text { Overburden stress } \\
(\mathrm{kPa})\end{array}$} & \multirow{2}{*}{$\mathbf{N}_{\mathrm{SPT}}$} & \multirow{2}{*}{$\mathbf{N}_{1(60)}$} & \multirow{2}{*}{$\mathbf{N}_{1(60) \text { cs }}$} & \multirow[t]{2}{*}{ CSR } & \multirow[t]{2}{*}{ CRR } & \multirow{2}{*}{$\mathrm{FS}_{\text {liq }}$} \\
\hline & & Total & Effective & & & & & & \\
\hline 1 & 3,50 & 55,30 & 55,30 & 6 & 8.01 & 8.01 & 0,32 & 0,09 & 0,28 \\
\hline 2 & 5,50 & 85,10 & 80,20 & 4 & 4.84 & 4.84 & 0,37 & 0,07 & 0,18 \\
\hline 3 & 7,50 & 122,10 & 97,58 & 13 & 15.45 & 15.45 & 0,17 & 0,17 & 0,45 \\
\hline 4 & 9,50 & 162,10 & 117,96 & 22 & 25.63 & 25.63 & 0,37 & 2,00 & 5,00 \\
\hline 5 & 11,50 & 200,10 & 136,34 & 26 & 29.69 & 29.69 & 0,37 & 0,43 & 1,17 \\
\hline 6 & 15,50 & 284,10 & 181,10 & 21 & 20.81 & 20.81 & 0,36 & 0,32 & 0,88 \\
\hline 7 & 17,50 & 322,70 & 200,08 & 19 & 17.91 & 17.91 & 0,36 & 0,19 & 0,54 \\
\hline 8 & 20,00 & 370,20 & 223,05 & 43 & 38.39 & 38.39 & 0,36 & 2,00 & 5,00 \\
\hline
\end{tabular}

Table 1

Liquefaction parameters obtained from SPT-values (RD1 site)

The results of liquefaction potential analysis performed for RD1 site is presented in Figure 5. The safety factor against liquefaction $F S_{\text {liq }}$ less than 1 was obtained for saturated sandy layers at the depth of $3.5,5.5,7.5,15.5$ and $17.5 \mathrm{~m}$, respectively in the points $1,2,3,6$ and 7. 


\subsection{Evaluation of soil liquefaction resistance using shear wave velocities results}

The preferable practice when using Vs measurements to evaluate liquefaction resistance is to drill sufficient boreholes and conduct sufficient tests to detect and delineate thin liquefiable strata, to identify non-liquefiable clay-rich soils, etc. One method of direct determination of dynamic soil properties in the field is to measure the velocity of shear waves in the soil. The waves are generated by impacts produced by a hammer or by detonating charges of explosives, and the travel times are recorded. This is usually done in or between boreholes. The use of Vs as an index of liquefaction resistance is justified since both Vs and liquefaction resistance are influenced by many of the same factors (void ratio, effective confining pressure, stress history, geologic age).
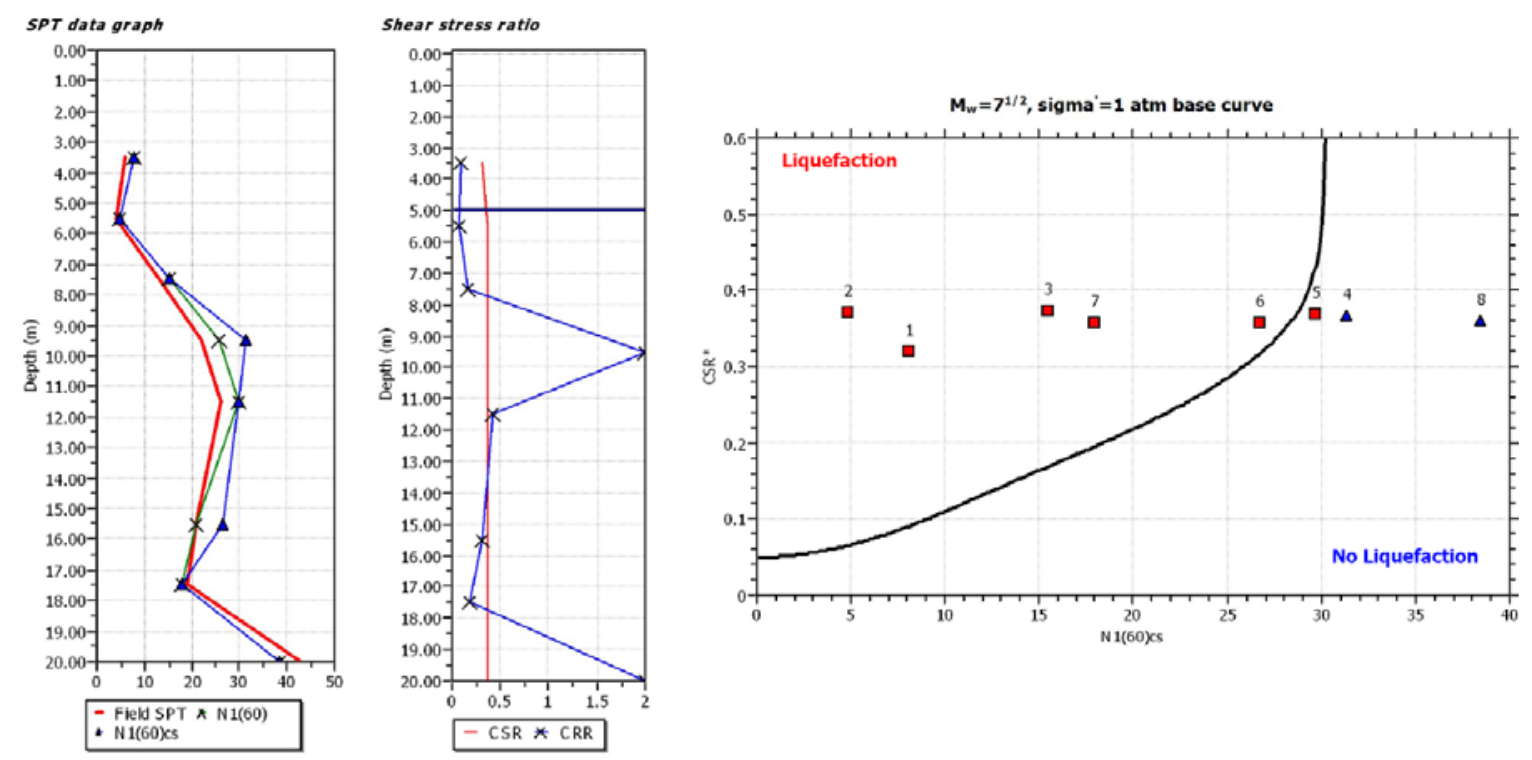

Fig. 5 - Assessment of soil liquefaction potential from SPT data for RD1 site

The resistance of the soil, expressed as the cyclic resistance ratio is generally established by separating liquefied cases from non-liquefied cases in actual earthquakes. Here, following empirical equation defined by [16] and [17] is used:

$$
\begin{aligned}
& C R R=\left\{a\left(\frac{V_{s 1}}{100}\right)^{2}+b\left(\frac{1}{c-V_{s 1}}\right)-\frac{1}{c}\right\} \\
& V_{s 1}=V_{S}\left(\frac{P a}{\sigma_{v}^{\prime}}\right)^{2}
\end{aligned}
$$

where:

a,b,c are parameters $(a=0.022, b=2.8, c=200 \sim 215 \mathrm{~m} / \mathrm{s})$,

$V_{s l}$ is the overburden stress corrected shear wave velocity defined by [18] as:

where:

$V_{\mathrm{s}}=$ measured shear-wave velocity $(\mathrm{m} / \mathrm{s}), \mathrm{Pa}=$ reference stress $(100 \mathrm{kPa}), \sigma_{\mathrm{v}}^{\prime}=$ initial effective overburden stress $(\mathrm{kPa})$.

The values of shear wave velocities used for the assessment of liquefaction potential are collected from geophysical measurements based on downhole (PRI site) and surface wave methods (SASW) for UTCB site. 
For the PRI site, the lithological profile is dominated by thick sandy and gravelly soils, with ground water table around 9,00 meters depth. On the UTCB site, the deposits are characterized by interposed thick sandy layers and clay lenses, with ground water table intercepted at 10,00 meters. The parameters calculated based on shear wave velocities corresponding to these locations are summary presented in Table 2 , respectively in Table 3.

Table 2

Liquefaction parameters obtained from Vs values for PRI site

\begin{tabular}{|c|c|c|c|c|c|c|c|c|}
\hline \multirow{2}{*}{ Point } & \multirow{2}{*}{$\begin{array}{c}\text { Depth } \\
(\mathbf{m})\end{array}$} & \multicolumn{2}{|c|}{$\begin{array}{c}\text { Overburden stress } \\
(\mathbf{k P a})\end{array}$} & $\begin{array}{c}\mathbf{V}_{\mathbf{s}} \\
(\mathbf{m} / \mathbf{s})\end{array}$ & $\begin{array}{c}\mathbf{V}_{\text {s1 }} \\
(\mathbf{m} / \mathbf{s})\end{array}$ & $\mathbf{C S R}$ & $\mathbf{C R R}$ & \multirow{2}{*}{ FS $_{\text {liq }}$} \\
\cline { 3 - 5 } & & Total & $\mathbf{E f f e c t i v e}$ & & & & \\
\hline 1 & 9,00 & 169,20 & 169,20 & 140 & 122,75 & 0,34 & 0,05 & 0,15 \\
\hline 2 & 20,00 & 373,80 & 265,89 & 280 & 219,27 & 0,28 & 2,00 & 5,00 \\
\hline
\end{tabular}

Table 3

Liquefaction parameters obtained from $\mathrm{V}_{\mathrm{s}}$ values for UTCB site

\begin{tabular}{|c|c|c|c|c|c|c|c|c|}
\hline \multirow{2}{*}{ Point } & \multirow{2}{*}{$\begin{array}{c}\text { Depth } \\
(\mathbf{m})\end{array}$} & \multicolumn{2}{|c|}{$\begin{array}{c}\text { Overburden stress } \\
\mathbf{( k P a )}\end{array}$} & $\begin{array}{c}\mathbf{V}_{\mathbf{s}} \\
\mathbf{( m / s )}\end{array}$ & $\begin{array}{c}\mathbf{V}_{\text {s1 }} \\
\mathbf{( m / s )}\end{array}$ & $\mathbf{C S R}$ & $\mathbf{C R R}$ & FS $_{\text {liq }}$ \\
\cline { 3 - 4 } & & $\mathbf{T o t a l}$ & $\mathbf{E f f e c t i v e}$ & & & & \\
\hline 1 & 0,50 & 9,00 & 9,00 & 165 & 301,25 & 0,19 & 2,00 & 5,00 \\
\hline 2 & 1,20 & 21,6 & 21,6 & 167 & 244,96 & 0,21 & 0,01 & 5,00 \\
\hline 3 & 1,90 & 34,2 & 34,2 & 160 & 209,22 & 0,26 & 0,34 & 1,33 \\
\hline 4 & 2,60 & 47,5 & 47,5 & 151 & 181,89 & 0,29 & 0,16 & 0,56 \\
\hline 5 & 3,50 & 64,6 & 64,6 & 154 & 171,78 & 0,31 & 0,12 & 0,41 \\
\hline 6 & 4,50 & 85,6 & 85,6 & 162 & 168,42 & 0,31 & 0,12 & 0,37 \\
\hline 7 & 5,50 & 106,6 & 106,6 & 167 & 164,35 & 0,32 & 0,11 & 0,34 \\
\hline 8 & 6,60 & 126,4 & 126,4 & 170 & 160,33 & 0,33 & 0,09 & 0,28 \\
\hline 9 & 7,80 & 145,6 & 145,6 & 172 & 156,58 & 0,34 & 0,09 & 0,25 \\
\hline 10 & 9,10 & 166,4 & 166,4 & 173 & 152,32 & 0,35 & 0,08 & 0,23 \\
\hline 11 & 10,40 & 192,4 & 188,4 & 173 & 147,65 & 0,34 & 0,08 & 0,24 \\
\hline 12 & 11,90 & 222,4 & 203,7 & 173 & 144,80 & 0,33 & 0,08 & 0,23 \\
\hline 13 & 13,40 & 249,4 & 216,1 & 172 & 141,87 & 0,33 & 0,07 & 0,21 \\
\hline 14 & 18,20 & 335,8 & 255,4 & 172 & 136,06 & 0,30 & 0,06 & 0,20 \\
\hline 15 & 20,00 & 368,2 & 270,1 & 182 & 141,97 & 0,29 & 0,07 & 0,24 \\
\hline
\end{tabular}

The graphical representations related to liquefaction potential analysis performed at PRI and UTCB sites based on shear wave velocities values are presented in Figure 6 and in Figure 7.

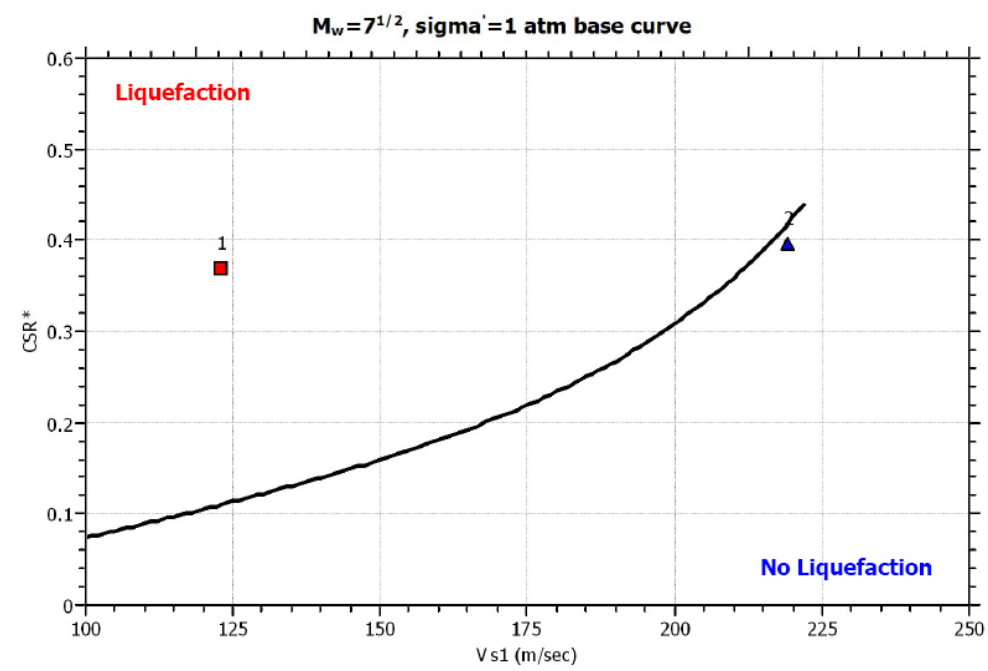

Fig. 6 - Assessment of soil liquefaction potential from $V_{s}$ data at PRI site 


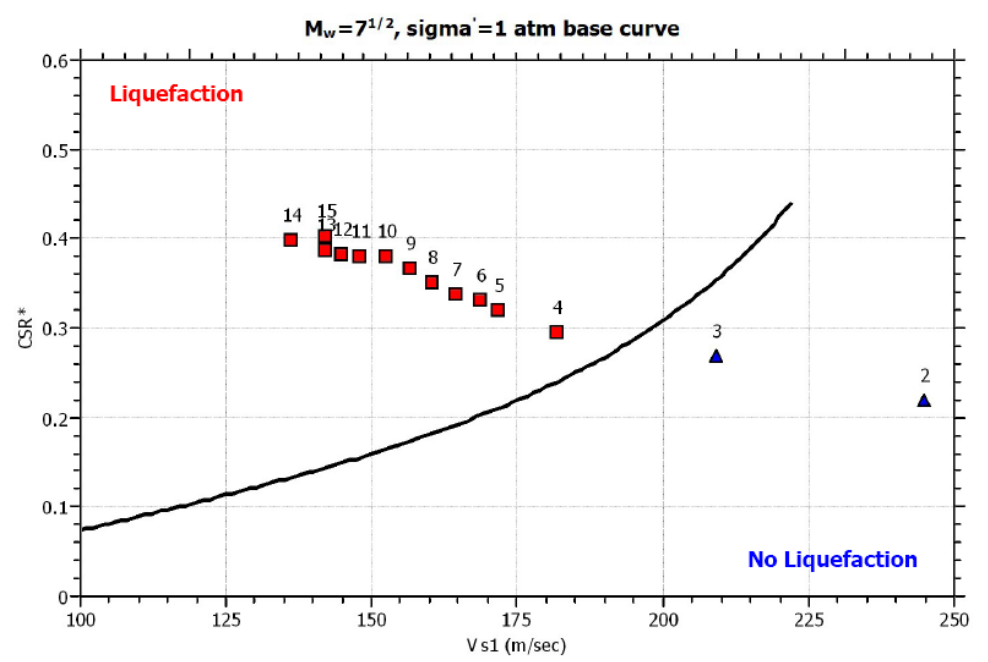

Fig. 7 - Assessment of soil liquefaction potential from $V_{s}$ data at UTCB site

Considering the liquefaction potential analysis at PRI site, the saturated sandy layer with 9,00 meters thickness is corresponding to safety factors against liquefaction less than 1, with certain liquefaction ( $\mathrm{LPI}=34 \%$ ) during an earthquake with parameters selected in the scenario. In case of UTCB site, it can be observed that the liquefied layers are extended up to the limit depth of analysis.

\section{Conclusions}

The different local soil conditions in Bucharest area lead to a variability of the soil response at seismic ground motions, which can occur at small distances and can be observed even for the same city area. This is the reason why in the case of the large urban areas, microzonation studies must take into account the mapping of the soil profile and the ground parameters. We have applied different methods for field investigation to evaluate the liquefaction potential of the sites. Taking into account the complexity and the importance of dynamic stability of cohesionless soil in building safety, it was considered useful to perform an analysis regarding the liquefaction potential assessment on Bucharest sites. The data processing highlights safety factors against liquefaction less than 1 and high liquefaction probabilities. Taking into consideration the correlation of soil characteristics, the sites can manifest liquefaction phenomenon during strong earthquakes. The liquefaction potential is related to the location of sites near Dambovita meadow, where recent alluvial deposits, saturated and non-cohesive soils at shallow depths are predominant. Creating an informational database concerning the characteristics of superficial geology of Bucharest is the basis for determining the correlation between seismic velocities and SPT results and soil parameters at seismic motions. The database will set basis for the requirements of Romanian seismic codes, harmonized with the European and international codes.

\section{Acknowledgements}

The paper was presented at the "5th National Conference on Earthquake Engineering and the 1st National Conference on Earthquake Engineering and Seismology", June 19-20 2014, Bucuresti"; it was published in the volume of the Conference.

\section{References}

[1]. Liteanu, E., (1951). Geology of Bucharest city zone, St.Tehn.Econ., E, 1, Bucharest (in Romanian)

[2]. Arion, C., 2004: Report on soil tests and investigations (laboratory and field experiments), JICA/CNRRS.

[3]. Bălan, Ştefan; Cristescu, Valeriu; Cornea, Ion: Cutremurul de pămant din Romậnia de la 4 martie 1977. Editura Academiei Republicii Socialiste Romậnia, Bucureşti, 1982. 
[4]. Hayashi, K, and Suzuki, H, (2004). "CMP cross-correlation analysis of multi-channel surface-wave data," Exploration Geophysics, Vol 35, pp7-13.

[5]. Youd, T.L., Idriss I.M., Andrus R., Arango I., Castro G., Christian J., Dobry R., Liam Finn W., Harder Jr. L., Hynes M.E., Ishihara K., Koester J., Liao S., Marcuson III W., Martin G., Mitchell J., Moriwaki Y., Power M., Robertson P., Seed R., Stokoe II K. (2001) „Liquefaction resistance of soils: summary report from the 1996 NCEER and 1998 NCEER/NSF workshops on evaluation of liquefaction of soils", Journal of Geotechnical and Geoenvironmental Engineering, ASCE, Vol. 127, No. 10, 817- 883.

[6]. Ishihara, K. \& Perlea V. (1984). Liquefaction-associated ground damage during the Vrancea earthquake of March 4, 1977, Soils and Foundations, Japanese Soc. of Soil Mech. And Found. Engineering, vol.24, no.1, 90-112.

[7]. Seed, H.B., Idriss, I.M. (1971). Simplified Procedure for Evaluating Soil Liquefaction Potential, J. Soil. Mech. Foundat. Div., ASCE vol. 97, no. SM9, 1971, 1249-1273.

[8]. Seed, H.B. (1979). Soil Liquefaction and Cyclic Mobility Evaluation for Level Ground During Earthquakes, J. Geotech. Engg Div., ASCE vol. 105, no. GT2, 201-255.

[9]. Seed, H.B., Idriss, I.M., Arango, I. (1983). Evaluation of Liquefaction Potential Using Field Performance Data, J. of Geotech. Eng vol. 109, no. 3, 458-482.

[10]. Seed, H.B., Tokimatsu, K., Harder, L.F., Chung, R.M. (1984). The Influence of SPT Procedures in Soil Liquefaction Resistance Evaluations, Report no. UCB/EERC-84/15. Berkeley, California.

[11]. Seed, H.B., Tokimatsu K., Harder L.F., Chung R. (1985). Influence of SPT procedures in soil liquefaction resistance evaluations, J. Geotechnical Eng., ASCE 111(12), 1425-1445.

[12]. NCEER (1997) "Proceedings of the NCEER Workshop on Evaluation of Liquefaction Resistance of Soils", Youd,T.L., Idriss,I.M., eds., Technical Report No. NCEER-97-0022, 41-88.

[13]. Ishihara K. (1985). Stability of natural deposits during earthquakes. In Eleventh International Conference on Soil Mechanics and Foundation Engineering, (pp. 321-376).

[14]. Ishihara, K. (1993). Liquefaction and flow failure during earthquakes, Geotechnique, Vol.43, No.3, pp.351- 415.

[15]. Seed, H.B., Harder L.F. (1990). SPT-based analysis of cyclic pore pressure generation and undrained residual strength, Proc. Seed Memorial Symposium, J.M. Duncan, BiTech Publishers, Vancouver, pp.351-376.

[16]. Andrus, R.D. \& Stokoe K.H. (1997). Liquefaction Resistance of Soils from Shear-Wave Velocity. In NCEER Workshop on Evaluation of Liquefaction Resistance of Soils, NCEER (pp. 89-128). Buffalo, USA.

[17]. Andrus, R.D., Stokoe K.H., Chung R.M. \& Juang C.H. (2003). Guidelines for evaluating liquefaction resistance using shear wave velocity measurements and simplified procedures, NIST GCR 03-854, MD.

[18]. Robertson, P.K., Woeller D.J., Finn W.D.L. (1992). Seismic Cone Penetration Test for evaluating liquefaction potential under cyclic loading, Canada Geotechnical Journal, Ottawa, Canada, vol.29, pp. 686-695. 